\title{
CONTEMPORARY QUALITY MANAGEMENT MODEL OF PROFESSIONAL SERVICES IN B2C AND B2B SYSTEMS COOPERATION
}

\author{
Dorota Klimecka-Tatar \\ Departmet of Production Engineering and Safety, Czestochowa University of Technology, \\ Dabrowskiego 69, 42-201, Czestochowa, slaskie, Poland \\ E-mail:dorota.klimecka-tatar@wz.pcz.pl
}

\begin{abstract}
In the paper the method for assessing the quality of professional services in the B2C (business to customer) and B2B (business to business) systems has been presented. The quality evaluation is analyzed according to relationships in the implementation of professional medical services (medical and prosthetic service). A dependence of information flow, knowledge management has been performed as a factor that builds mutual trust between the client (patient), service provider (dentist) and subcontractor (dental technician). The quality management model in the context of B2C and B2B cooperation has been emphasized.
\end{abstract}

Keywords: B2C system, B2B system, knowledge management, quality, service.

JEL Classification: O21, O14, L84, O15, O32, O33, M11.

\section{Introduction}

In the concept of business management, cooperation between entities is treated as a comprehensive process, taking place at several stages - the type of established relationships, setting requirements, implementing and releasing the project. During such a process, a decision is made gradually from the so-called general decision to the final product selection with strictly defined parameters by the customer in terms of technical quality, delivery date, quantity, and (in many cases) service package, technical consultancy, periodic maintenance inspections guarantees whether removal of damage (Liu, Foscht, Eisingerich, \& Tsai, 2017).

It is well known that, the process is the entire system of activity (along with related material and non-material resources), the operation of which depends on downloading input data and transforming it into a product/service with a specific value (value estimated by the client) (Meidutè-Kavaliauskienè, Aranskis, \& Litvinenko, 2014; Ulewicz \& Kucęba, 2016). Therefore, the value of the product/service depends on the activities included in the process. One of the most important determinants is the estimation of the level of quality of the implemented process at each stage - it is also the basis of management in accordance with TQM principles and in relation to quality management standards ISO 9001:2015 (Cheng, Choi, \& Wong, 2016, Kasiri, Guan
Cheng, Sambasivan, \& Sidin, 2017; Kowalik \& Klimecka-Tatar, 2017; Nowacki, Szopiński, \& Bachnik, 2017; White, Nallur, \& Clarke, 2017). The principles of quality management (based on the notation in the international standard) refer to the 7 most important areas (Murphy \& Sashi, 2018; Pansari \& Kumar, 2017):

1. Customer orientation. The organization is able to achieve the success only with the trust of customers.

2. Leadership. Managers at all levels in the organization should create conditions for achieving the set goals.

3. Commitment of people. To effectively manage the organization, it is important to involve all people at all levels - encourage involvement by identifying and developing competences, selecting appropriate personnel.

4. Process approach. The expected results are achieved more effectively if the organization's management is based on processes.

5. Continuous improvement. Organization management with emphasis on continuous improvement - the investigation possibilities of development and competitiveness increasing.

6. Evidence-based decision making. Factual, evidence and data analysis lead to greater objectivity and certainty in decisions making. 
7. Mutual benefits in relations with stakeholders. For long-term success, the organization should look after good relationships with external stakeholders by stable goods and services flow, identifying priorities etc.

There are many methods of assessing the quality of process, as well as assessing of service quality (e.g. Çifci et al., 2016; Chu \& Hsu, 2017; Gulc, 2017; Ingaldi, 2016; Lee \& Cheng, 2018).

\section{2. $B 2 B$ and $B 2 C$ relation in the implementa- tion of the organization's tasks}

Under the terms Business to Business (B2B) and Business to Consumer (B2C), there is a very wide range of relationships between organizations and clients. In the simplest terms, these are relations between companies, in the case of the B2B model or between companies and clients, in the case of the $\mathrm{B} 2 \mathrm{C}$ model. In most literature refer to internet marketing in relation $\mathrm{B} 2 \mathrm{~B}$ and B2C (Brink, 2017; Dant \& Brown, 2008; Iankova, Davies, Archer-Brown, Marder, \& Yau, 2018; Lilien, 2016; Lussier \& Hall, 2017). However, it should be emphasized that building relationships in these systems requires definitely more engagement than just marketing activities. Both $\mathrm{B} 2 \mathrm{~B}$ and $\mathrm{B} 2 \mathrm{C}$ are relationships in which various transactions are concluded. However, it cooperates differently with other companies, and differently with individual clients. The scale of business and the purpose and costs of services are also completely different.

Characteristics of these two issues should start with the description of the Business to Business relationship. In the case of B2B activities, there is the cooperation between small groups of people from specific industry (appropriately selected to the target group). The strength of cooperation is determined by business loyalty, negotiable conditions, partnership agreements, etc. (Gharib, Philpott, \& Duan, 2017). Such a relationship is a network in which, there are main service providers and producers, and each of them is equally important. Everyone plays key roles in the production and distribution of products/services. As part of B2B cooperation, it has to be mention:

- preparation and confirmation of offers and orders,

- cyclic nature of the transaction,

- adapting to the needs and requirements of the partner,
- extensive offer and a complex order system,

- financial connections - regulation based on invoices,

- development of projects and documents related to the execution of transactions,

- marketing support.

Working within the business to business relationships can be active on two types of markets:

- on the vertical market where it trades within one industry that directly covers goods related to production,

- on a horizontal market that covers various industries and often sells products and services not directly related to production.

The B2C, business to customer, relationship takes place in situation that a company contacts directly with clients. In B2C the number of clients can be very large, the value of the transaction per one buyer could be quite small (Vrontis, Thrassou, \& Amirkhanpour, 2017). Companies operating within $\mathrm{B} 2 \mathrm{C}$ deal with the preparation and confirmation of offers and orders, the execution of transactions, issuing documents related to the execution of transactions as well as deal with professional consultations. Business-to-business (B2B) often develops highly customized offerings for their customers. Customizing B2B professional services is knowledge of intensive process that requires the coordinated efforts of individuals with specialized knowledge and skills (Madhavaram \& Hunt, 2017). As part of B2C cooperation, it has to be mention:

- no-cyclic nature of the transaction,

- customers buy products and services for individual use,

- all customers pay exactly the same price for selected products,

- after the end of the service, the customer pays cash,

- offer is an uncomplicated.

By character, the B2B and B2C are two completely different types of relationships in creating cooperation between entities - there is no possibility of confusion between one type of relationship with another (Zolkiewski et al., 2017). The most important thing is that the basic difference in the $\mathrm{B} 2 \mathrm{~B}$ and $\mathrm{B} 2 \mathrm{C}$ segments is the nature of the needs that in both cases try to meet. B2B transactions are focused on business needs - all activities are focused on tools and means to achieve specific goals. On the other hand $\mathrm{B} 2 \mathrm{C}$ transactions are focused on human 
needs. In this model, the activities are focused on the consumer.

\section{Methodology and approach}

The implementation of activities of enterprises and cooperators in service and production processes of a specialized nature is burdened with a large range of requirements and duties, starting from legal requirements, extensive specialist knowledge, through experience, practice and commitment. It can be concealed that in the implementation of special (medical) processes, the competences of process participants at every stage of implementation are very important. In this paper the attention to the complexity of medical service combined with prosthetic treatment has been paid. The medical process (dental and prosthetic treatment), in accordance to production and service management, has a two-stage: first in the field of medical services and in the scope of the manufacturing process of a unitary engineering product (denture prosthesis) (Gutacker, Harris, Brennan, \& Hollingsworth, 2015; Klimecka-Tatar, 2017).

It has been observed that this kind of medical service combined with prosthetic treatment has concurrently functioning two models of relationships - parallel levels of B2B and B2C cooperation. In Figure 1 the conceptual framework of study is presented.

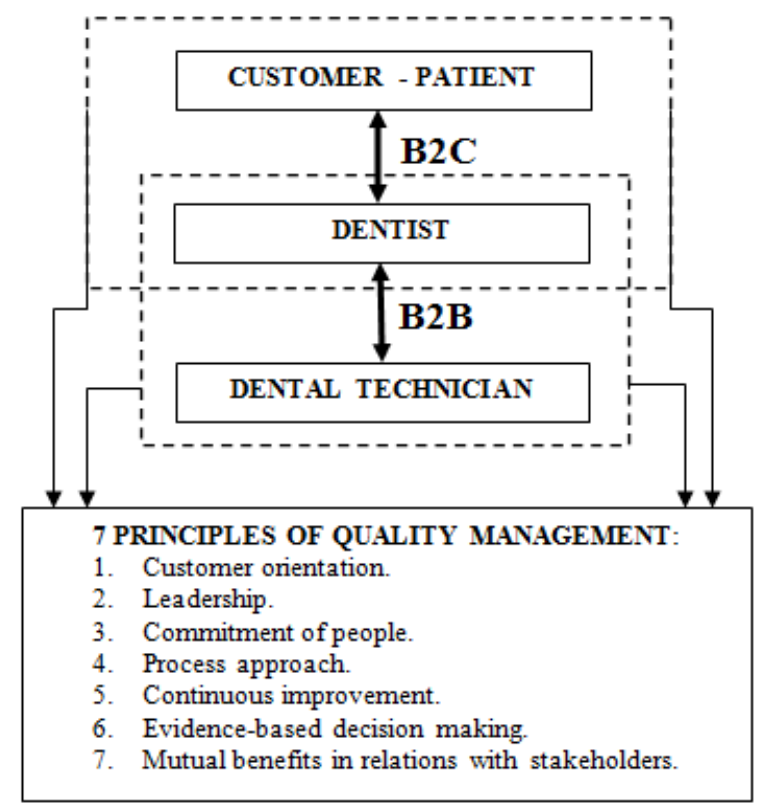

Figure 1. The conceptual framework of study under parallel levels of B2B and B2C cooperation in professional medical service medical combined with prosthetic treatment (source: own study)
As part of this study, a number of surveys research have been carried. The questionnaire was directed to three groups of respondents (participants of $\mathrm{B} 2 \mathrm{C}$ and $\mathrm{B} 2 \mathrm{~B}$ relations presented in Figure 1). The group of participants is:

- patients undergoing medical treatment in combination with prosthetic treatment -200 of respondents,

- dentists providing specialist services (medical consultations and prosthetic treatment) -30 of respondents,

- dental technicians providing readymade products (dentures) to dentists 60 of respondents.

Three groups of respondents received a questionnaire with 7 questions to complete. The questions in their content correspond to the next (appropriate) principle of quality management:

1. Customer orientation.

2. Leadership.

3. Commitment of people.

4. Process approach.

5. Continuous improvement.

6. Evidence-based decision making.

7. Mutual benefits in relations with stakeholders.

The group of dentists answered 7 questions from the point of view of the relationship with the client (the patient) and from the point of view of the relationship with the subcontractor (dental technician).

\section{Results and discussion}

In Table 1 and 2 the sets of question to three group of respondent are presented. Participants of the study answered by assigning the appropriate question with note on a scale from 0 to 5 , with 5 -yes, I fully agree, 0 - no, I completely disagree. Tables 3-6 the rating structures of the questions in accordance to 7 principles of quality management in B2C (Table 3 and 4) and B2B (Table 5 and 6) have been presented.

Table 1. The sets of questions in accordance to 7 principles of quality management in $\mathrm{B} 2 \mathrm{C}$ relation (source: own study)

\begin{tabular}{|l|l|}
\hline \multicolumn{2}{|c|}{ B2C RELATION } \\
\hline PATIENT & \multicolumn{1}{c|}{$\begin{array}{c}\text { DENTIST } \\
\text { (vs. PATIENT) }\end{array}$} \\
\hline 1. Customer orientation \\
\hline $\begin{array}{l}\text { Do you meet your } \\
\text { current expectations } \\
\text { during the visit? }\end{array}$ & $\begin{array}{l}\text { Do you meet the expec- } \\
\text { tations of the patient } \\
\text { during the visit? }\end{array}$ \\
\hline
\end{tabular}


End of Table 1

\begin{tabular}{|c|c|}
\hline \multicolumn{2}{|c|}{ B2C RELATION } \\
\hline PATIENT & $\begin{array}{c}\text { DENTIST } \\
\text { (vs. PATIENT) }\end{array}$ \\
\hline \multicolumn{2}{|l|}{ 2. Leadership } \\
\hline $\begin{array}{l}\text { Do you feel that all } \\
\text { employees cooperate } \\
\text { with each other during } \\
\text { the visit? }\end{array}$ & $\begin{array}{l}\text { Do you feel that all em- } \\
\text { ployees cooperate with } \\
\text { each other during the } \\
\text { visit? }\end{array}$ \\
\hline \multicolumn{2}{|c|}{ 3. Commitment of people } \\
\hline $\begin{array}{l}\text { Do you feel the full } \\
\text { involvement of the } \\
\text { staff during the visit? }\end{array}$ & $\begin{array}{l}\text { Do you feel staff in- } \\
\text { volvement during the } \\
\text { visit? }\end{array}$ \\
\hline \multicolumn{2}{|l|}{ 4. Process approach } \\
\hline $\begin{array}{l}\text { Is the service imple- } \\
\text { mentation professional } \\
\text { and runs according to } \\
\text { the scheme? }\end{array}$ & $\begin{array}{l}\text { Is the service implemen- } \\
\text { tation professional and } \\
\text { runs according to the } \\
\text { scheme? }\end{array}$ \\
\hline \multicolumn{2}{|c|}{ 5. Continuous improvement } \\
\hline $\begin{array}{l}\text { Do you observe favor- } \\
\text { able changes in the } \\
\text { quality of the service } \\
\text { during subsequent vis- } \\
\text { its? }\end{array}$ & $\begin{array}{l}\text { Is the quality of the ser- } \\
\text { vice being improved on } \\
\text { the basis of improve- } \\
\text { ment tools? }\end{array}$ \\
\hline \multicolumn{2}{|c|}{ 6. Evidence-based decision making } \\
\hline $\begin{array}{l}\text { Are decisions about } \\
\text { the method of pros- } \\
\text { thetic treatment based } \\
\text { on irrefutable evi- } \\
\text { dence? }\end{array}$ & $\begin{array}{l}\text { Are decisions about the } \\
\text { method of prosthetic } \\
\text { treatment based on irref- } \\
\text { utable evidence? }\end{array}$ \\
\hline \multicolumn{2}{|c|}{ 7. Mutual benefits in relations with stakeholders } \\
\hline $\begin{array}{l}\text { Are positive relation- } \\
\text { ships established dur- } \\
\text { ing the visit? }\end{array}$ & $\begin{array}{l}\text { Are positive relation- } \\
\text { ships established during } \\
\text { the visit? }\end{array}$ \\
\hline
\end{tabular}

On the basis of the comparison of results (Figure 2a $\div$ g), it can be noticed that in the patient-dentist relation, dentists assess the quality management method in the $\mathrm{B} 2 \mathrm{C}$ relation much better. Dentists were much more likely to allocate high scores (they agreed) to all questions representing the appropriate principles of quality management. Patients, on the other hand, were not unambiguous in their assessments, which results from the considerable dispersion of notes. Significant differences have been noted in the Figure 2d, 2f, 2g, that respectively correspond to principle 4 - process approach, principle 6 - evidence-based decision making, and principle 7 - mutual benefits in relations with stakeholders. The results of the evaluations indicate that according to dentists, the selected principles are fully met. While patients have considerable doubts about the quality of management in these areas. Interestingly, dentists disadvantageous assessments assigned to the questions relating to service process improvement (Figure 2e) - confirming that they do not use any improvement instruments. While patients see the elements of improvement in the service delivery process.

Table 2. The sets of questions in accordance to 7 principles of quality management in $\mathrm{B} 2 \mathrm{~B}$ relation (source: own study)

\begin{tabular}{|c|c|}
\hline \multicolumn{2}{|c|}{ B2C RELATION } \\
\hline $\begin{array}{c}\text { DENTIST } \\
\text { (vs. PATIENT) }\end{array}$ & $\begin{array}{c}\text { DENTAL } \\
\text { TECHNICIAN }\end{array}$ \\
\hline \multicolumn{2}{|l|}{ 1. Customer orientation } \\
\hline $\begin{array}{l}\text { Do you always meet } \\
\text { your expectations } \\
\text { while orders complet- } \\
\text { ing by a dental techni- } \\
\text { cian? }\end{array}$ & $\begin{array}{l}\text { Do you meet the current } \\
\text { expectations of the den- } \\
\text { tist during orders com- } \\
\text { pleting? }\end{array}$ \\
\hline \multicolumn{2}{|l|}{ 2. Leadership } \\
\hline $\begin{array}{l}\text { Do you feel that all } \\
\text { employees cooperate } \\
\text { with each other during } \\
\text { the orders completing? }\end{array}$ & $\begin{array}{l}\text { Do you feel that all em- } \\
\text { ployees cooperate with } \\
\text { each other during the } \\
\text { orders completing? }\end{array}$ \\
\hline \multicolumn{2}{|c|}{ 3. Commitment of people } \\
\hline $\begin{array}{l}\text { Do you feel dental } \\
\text { technician involve- } \\
\text { ment during the orders } \\
\text { completing? }\end{array}$ & $\begin{array}{l}\text { Do you feel dentist in- } \\
\text { volvement during the } \\
\text { orders completing? }\end{array}$ \\
\hline \multicolumn{2}{|l|}{ 4. Process approach } \\
\hline $\begin{array}{l}\text { Is the order completing } \\
\text { professional and runs } \\
\text { according to the } \\
\text { scheme? }\end{array}$ & $\begin{array}{l}\text { Is the order completing } \\
\text { professional and runs } \\
\text { according to the } \\
\text { scheme? }\end{array}$ \\
\hline \multicolumn{2}{|c|}{ 5. Continuous improvement } \\
\hline $\begin{array}{l}\text { Is the method of com- } \\
\text { munication and orders } \\
\text { completing being im- } \\
\text { proved on the basis of } \\
\text { improvement tools? }\end{array}$ & $\begin{array}{l}\text { Is the method of com- } \\
\text { munication and orders } \\
\text { completing being im- } \\
\text { proved on the basis of } \\
\text { improvement tools? }\end{array}$ \\
\hline \multicolumn{2}{|c|}{ 6. Evidence-based decision making } \\
\hline $\begin{array}{l}\text { Are decisions about } \\
\text { the prosthetic restora- } \\
\text { tion project based on } \\
\text { professional technical } \\
\text { data? }\end{array}$ & $\begin{array}{l}\text { Are decisions about the } \\
\text { prosthetic restoration } \\
\text { project based on profes- } \\
\text { sional technical data? }\end{array}$ \\
\hline \multicolumn{2}{|c|}{ 7. Mutual benefits in relations with stakeholders } \\
\hline $\begin{array}{l}\text { Are positive relation- } \\
\text { ships established dur- } \\
\text { ing the cooperation } \\
\text { with dental technician? }\end{array}$ & $\begin{array}{l}\text { Are positive relation- } \\
\text { ships established during } \\
\text { the cooperation with } \\
\text { dentist? }\end{array}$ \\
\hline
\end{tabular}


Table 3. The rating structure of the questions in accordance to 7 principles of quality management in $\mathrm{B} 2 \mathrm{C}$ relation - questionnaire addressed to clients (source: own study)

\begin{tabular}{|c|c|c|c|c|c|c|}
\hline \multirow{2}{*}{ No. } & \multicolumn{7}{|c|}{ Rate (5-yes, I fully agree, } \\
\cline { 2 - 7 } & 0 & 1 & 2 & 3 & 4 & 5 \\
\cline { 2 - 7 } & \multicolumn{7}{|c|}{ Rating structure } \\
\hline 1. & 5 & 15 & 8 & 46 & 78 & 48 \\
\hline 2. & 25 & 38 & 41 & 72 & 5 & 19 \\
\hline 3. & 3 & 78 & 36 & 41 & 32 & 10 \\
\hline 4. & 4 & 9 & 19 & 51 & 92 & 25 \\
\hline 5. & 112 & 1 & 18 & 32 & 30 & 7 \\
\hline 6. & 35 & 42 & 19 & 28 & 31 & 45 \\
\hline 7. & 32 & 18 & 23 & 51 & 42 & 34 \\
\hline
\end{tabular}

Table 4. The rating structure of the questions in accordance to 7 principles of quality management in $\mathrm{B} 2 \mathrm{C}$ relation - questionnaire addressed to dentist (source: own study)

\begin{tabular}{|c|c|c|c|c|c|c|}
\hline \multirow{2}{*}{ No. } & \multicolumn{7}{|c|}{ Rate (5 - yes, I fully agree, } \\
\cline { 2 - 7 } & 0 & 1 & 2 & 3 & 4 & 5 \\
\cline { 2 - 7 } & \multicolumn{7}{|c|}{ Rating structure } \\
\hline 1. & 0 & 0 & 0 & 5 & 16 & 9 \\
\hline 2. & 0 & 0 & 0 & 6 & 7 & 17 \\
\hline 3. & 0 & 1 & 1 & 2 & 12 & 14 \\
\hline 4. & 0 & 0 & 0 & 0 & 1 & 29 \\
\hline 5. & 1 & 1 & 6 & 17 & 3 & 2 \\
\hline 6. & 0 & 0 & 0 & 0 & 2 & 28 \\
\hline 7. & 0 & 0 & 0 & 0 & 4 & 26 \\
\hline
\end{tabular}

a)

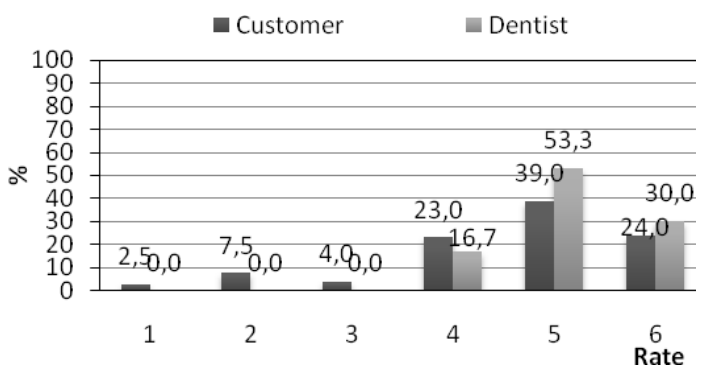

b)

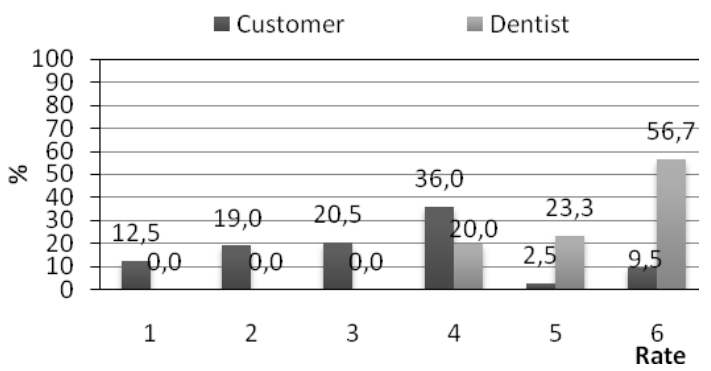

c)

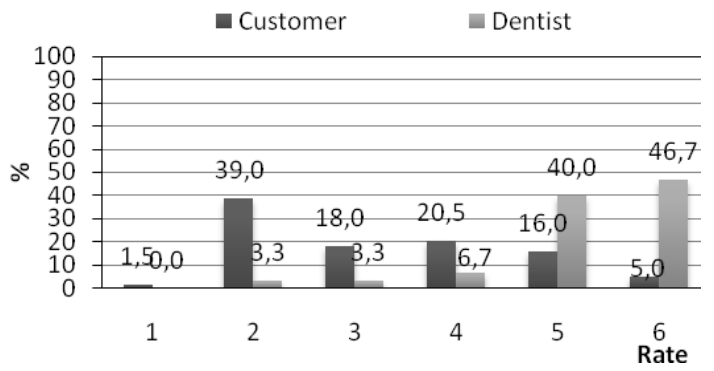

d)

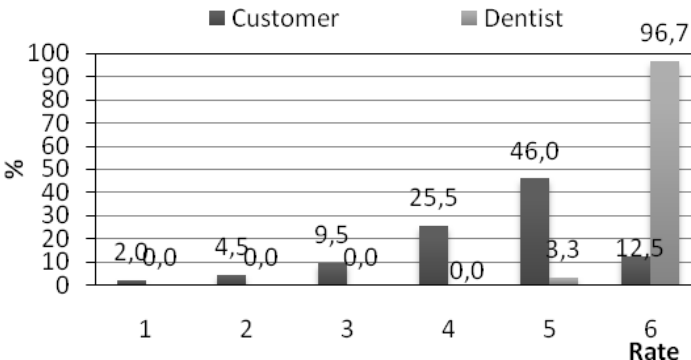

e)

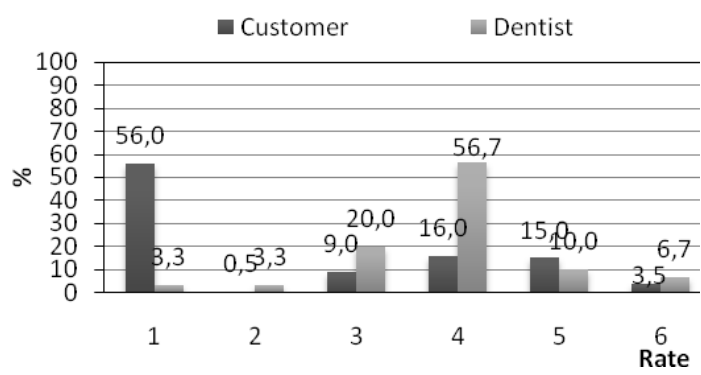

f)

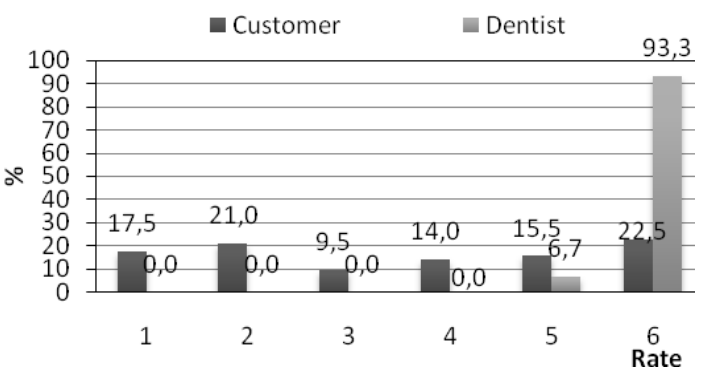

g)

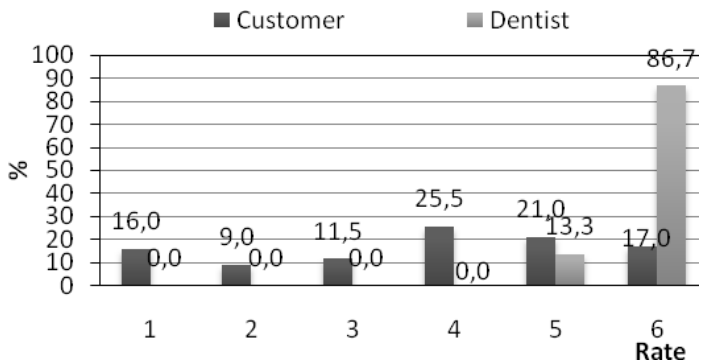

Figure 2. The percentage structure of the evaluation in $\mathrm{B} 2 \mathrm{C}$ relation: a) customer orientation; b) leadership; c) commitment of people; d) process approach; e) continuous improvement; f) evidence-based decision making; g) mutual benefits in relations with stakeholders (source: own study) 
Table 5. The rating structure of the questions evaluation in accordance to 7 principles of quality management in $\mathrm{B} 2 \mathrm{~B}$ relation - questionnaire addressed to dentist (source: own study)

\begin{tabular}{|c|c|c|c|c|c|c|}
\hline \multirow{2}{*}{ No. } & \multicolumn{7}{|c|}{ Rate (5 - yes, I fully agree, } \\
\cline { 2 - 7 } & 0 & 1 & 2 & 3 & 4 & 5 \\
\cline { 2 - 7 } & \multicolumn{7}{|c|}{ Rating structure } \\
\hline 1. & 0 & 13 & 5 & 5 & 4 & 3 \\
\hline 2. & 1 & 12 & 4 & 5 & 6 & 2 \\
\hline 3. & 0 & 1 & 2 & 1 & 11 & 15 \\
\hline 4. & 6 & 3 & 13 & 2 & 2 & 4 \\
\hline 5. & 18 & 3 & 2 & 0 & 0 & 7 \\
\hline 6. & 0 & 0 & 9 & 1 & 2 & 18 \\
\hline 7. & 0 & 0 & 1 & 15 & 3 & 11 \\
\hline
\end{tabular}

Table 6. The rating structure of the questions evaluation in accordance to 7 principles of quality management in B2B relation - questionnaire addressed to dental technician (source: own study)

\begin{tabular}{|c|c|c|c|c|c|c|}
\hline \multirow{2}{*}{ No. } & \multicolumn{7}{|c|}{ Rate (5-yes, I fully agree, } \\
\cline { 2 - 7 } & 0 & 1 & 2 & 3 & 4 & 5 \\
\cline { 2 - 7 } & \multicolumn{7}{|c|}{ Rating structure } \\
\hline 1. & 1 & 1 & 2 & 14 & 21 & 21 \\
\hline 2. & 2 & 18 & 21 & 12 & 3 & 4 \\
\hline 3. & 1 & 2 & 10 & 11 & 28 & 8 \\
\hline 4. & 4 & 10 & 16 & 18 & 7 & 5 \\
\hline 5. & 4 & 32 & 16 & 2 & 2 & 4 \\
\hline 6. & 2 & 21 & 14 & 6 & 5 & 12 \\
\hline 7. & 2 & 7 & 21 & 23 & 3 & 4 \\
\hline
\end{tabular}

a)

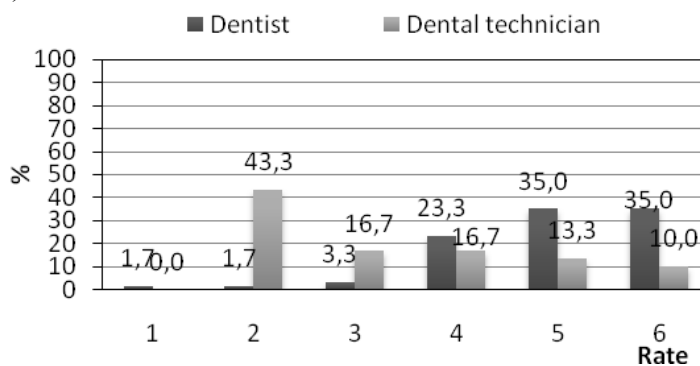

b)

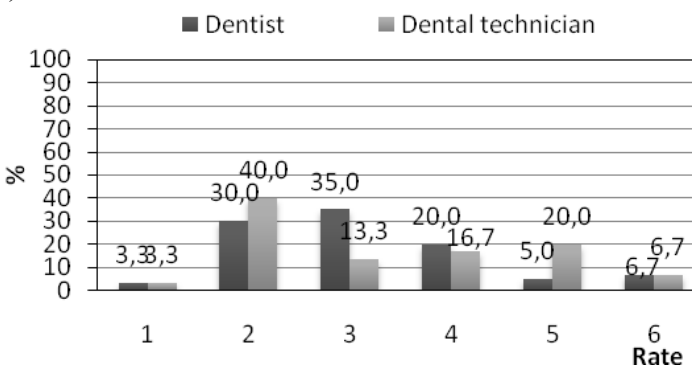

c)

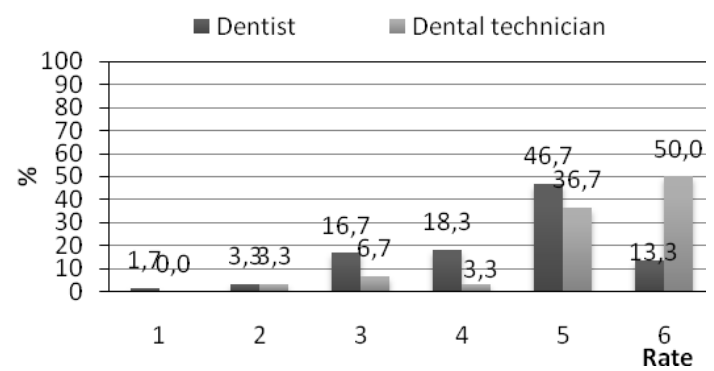

d)

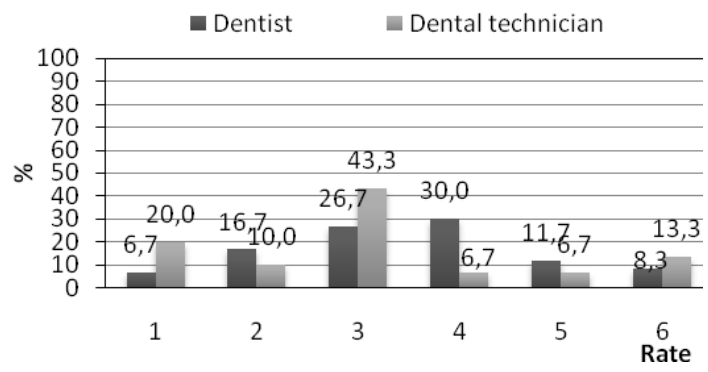

e)

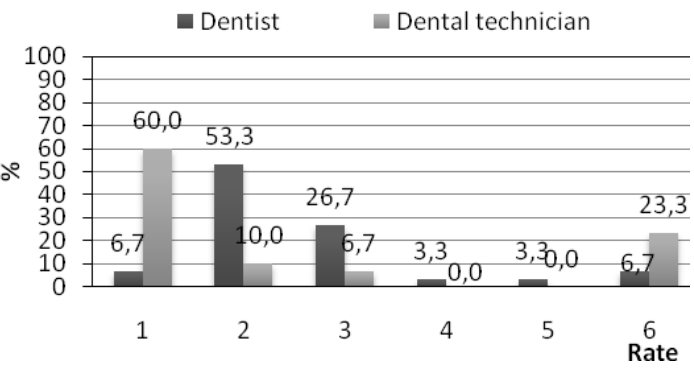

f)

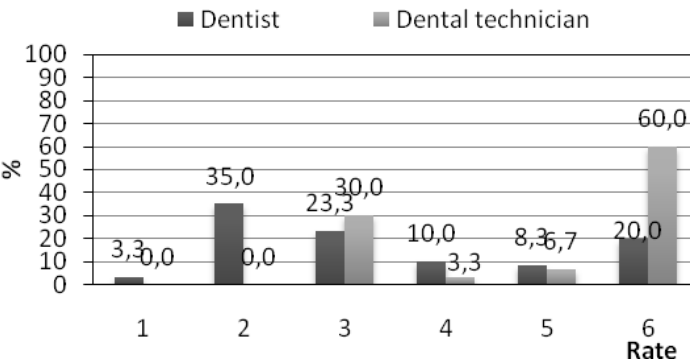

g)

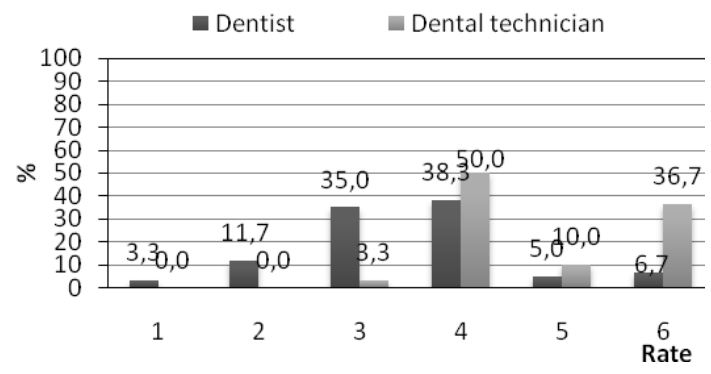

Figure 3. The percentage structure of the evaluation in B2B relation: a) customer orientation; b) leadership; c) commitment of people; d) process approach; e) continuous improvement; f) evidence-based decision making; g) mutual benefits in relations with stakeholders (source: own study) 
With reference to the comparison shown in Figure $3 \mathrm{a} \div \mathrm{g}$, it can be seen that dentists did not allocate such optimistic assessments when assessing the quality of relationships with dental techniques (B2B). A greater criticism as to the fulfillment of quality management principles results from the fact that in this relationship they are not the decision-maker. In Figure 3a, Figure $3 \mathrm{f}$ and Figure $3 \mathrm{~g}$ it is possible to note a clear divergence of views in context of customer orientation, decision making based of evidencebased, mutual benefits in relations with stakeholders. It is possible to observe a significant compatibility in perception of leadership (Figure $3 \mathrm{a}$ ), process approach (Figure $3 \mathrm{~d}$ ) and continuous improvement (Figure $3 \mathrm{f}$ ).

In order to illustrate the difference in perception of meeting the 7 principles of quality management, the average of the results obtained for each question and for each group of respondents was calculated. The average rating $\left(Z_{q}\right)$ is calculated on the basis of formula (1).

$$
\bar{Z}_{q}=\sum \frac{N_{i \cdot x_{i}}}{n},
$$

where: $N$ - rate $(0 \div 5) ; x$ - the number of ratings; $n$-the number of respondents in the discussed group.

In Table 7 there is presented the comparison of average ratings in accordance to 7 principles of quality management in relation between customer (patient) and dentist as a service provider (B2C). The results confirm the quite idealistic approach of dentists to the method of managing the quality of the service delivery process. The smallest difference between the perceptions of quality has been noted for principle 1, i.e. customer orientation (Figure 4). Which means that customers feel that their expectations are largely met and the created relationship causes increase of customer trust? Consumer trust is often described as the mental condition when customers believe that the current service provider could not be replaced as cause better or equal alternative exists in the market and such customer dependency has been frequently used as a term related to expected benefits (Ashley, Noble, Donthu, \& Lemon, 2011; Gao, Sirgy, \& Bird, 2005; Fatima \& Di Mascio, 2018). The biggest differences between the perception of quality have been noted for principles 2 (Leadership) and 7 (Mutual benefits in relations with stakeholders). The difference in perception of quality in this area between the assessment of clients and dentists is over 2 .

Table 7. The comparison of average ratings in accordance to 7 principles of quality management in $\mathrm{B} 2 \mathrm{C}$ relation (source: own study)

\begin{tabular}{|l|l|}
\hline \multicolumn{2}{|c|}{ B2C RELATION } \\
\hline PATIENT & \multicolumn{1}{c|}{ DENTIST } \\
1. Customer orientation \\
\hline 3.61 & 4.13 \\
\hline 2. Leadership & 4.37 \\
\hline 2.26 & 4.23 \\
\hline 3. Commitment of people \\
\hline 2.26 & 4.97 \\
\hline 4. Process approach \\
\hline 3.47 \\
\hline 5. Continuous improvement \\
\hline 1.44 & 2.87 \\
\hline 6. Evidence-based decision making \\
\hline 2.57 & 4.93 \\
\hline 7. Mutual benefits in relations with stakeholders \\
\hline 2.78 & 4.87 \\
\hline
\end{tabular}

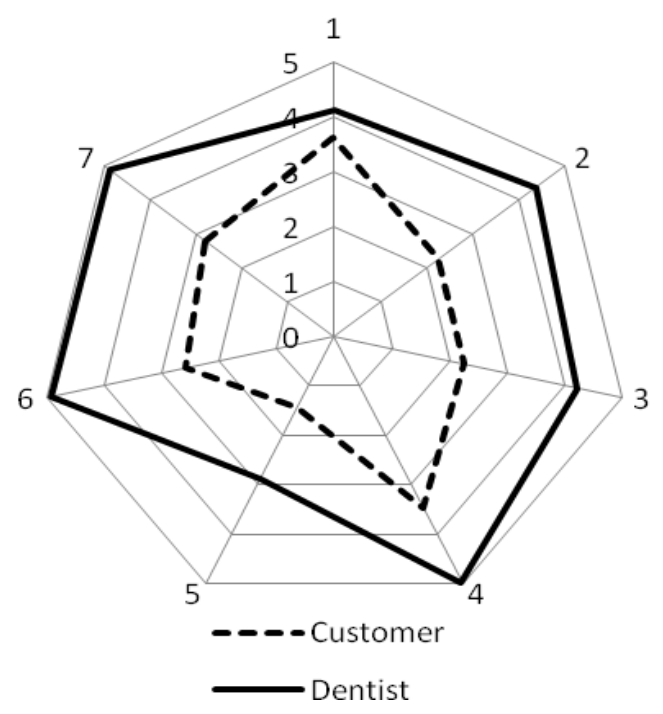

Figure 4. The comparison of average ratings in accordance to 7 principles of quality management in $\mathrm{B} 2 \mathrm{C}$ relation - radar diagram (source: own study)

In Table 8 there is presented the comparison of average ratings in accordance to 7 principles of quality management in relation between dentist and dental technician (B2B). The comparison of values indicates a much greater consistency in the fulfillment of conditions in the principle of quality management between dentists and dental technicians. Consistent compliance has been not- 
ed for the quality management principles 2 (Leadership), 4 (Process approach) and 5 (Continuous improvement) - Figure 5.

Table 8. The comparison of average ratings in accordance to 7 principles of quality management in B2B relation (source: own study)

\begin{tabular}{|l|l|}
\hline \multicolumn{2}{|c|}{ B2C RELATION } \\
$\begin{array}{l}\text { DENTIST } \\
\text { vs. PATIENT) }\end{array}$ & $\begin{array}{c}\text { DENTAL } \\
\text { TECHNICIAN }\end{array}$ \\
\hline 1. Customer orientation \\
\hline 2.30 & 3.93 \\
\hline 2. Leadership & 2.13 \\
\hline 2.30 \\
\hline 3. Commitment of people \\
\hline 4.23 & 3.45 \\
\hline 4. Process approach \\
\hline 2.10 \\
\hline 5. Continuous improvement \\
\hline 1.40 & 1.63 \\
\hline 6. Evidence-based decision making \\
\hline 3.97 & 2.45 \\
\hline 7. Mutual benefits in relations with stakeholders \\
\hline 3.80 & 2.50 \\
\hline
\end{tabular}

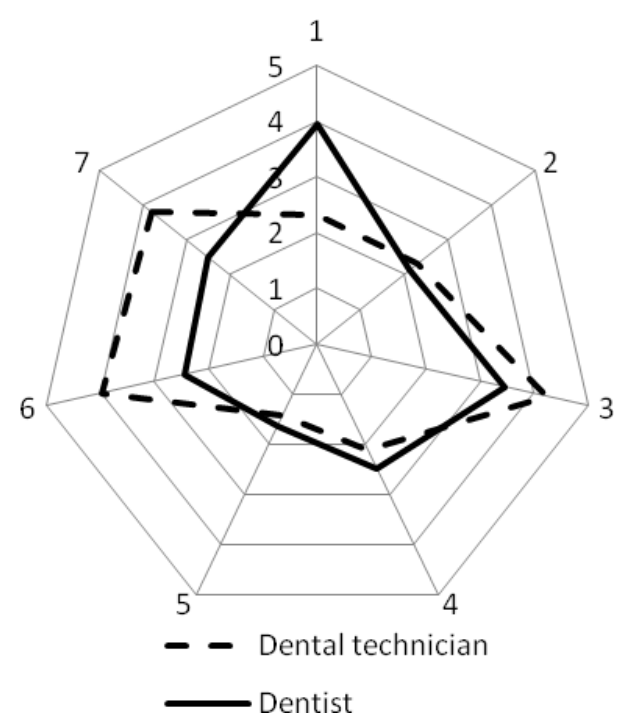

Figure 5. The comparison of average ratings in accordance to 7 principles of quality management in B2B relation - radar diagram (source: own study)

However, slight differences in the discrepancy in the quality of B2B relations do not mean that they are positive, the average score below 3 is not satisfactory enough, and rather it should be a factor that will initiate strong changes in the way of building cooperation.
The biggest differences between the perception of quality have been noted for principles 1 (Customer orientation) and 6 (Evidence-based decision making). The difference in perception of quality in this area between the assessment of dentist and dental technical is below 2 .

\section{Limitations and future research}

Limitations and further research and analysis of relation between customer (patient) - dentist and dentist - dental technician could be represented by novel approach to examining the impact of a management principles also in micro and small and medium companies SMEs. However, due to the limitation of the available variables in the dataset of principles it is worth to notice that new sets of analyses with the given approach could indicate the need of applying the growth strategy.

\section{Conclusions}

Considering the unique features of the medical services market with regard to both the extension of the offer and the acquisition of a clients group, organizations operating in the $\mathrm{B} 2 \mathrm{C}$ and $\mathrm{B} 2 \mathrm{~B}$ associations (especially where the systems cooperate in parallel) must be carefully managed to ensure their contribution to profits. Based on the literature review, it has been pointed out that there are not too many studies considering the satisfaction and quality in such specific B2C and $\mathrm{B} 2 \mathrm{~B}$ arrangements with regard to specialist services - professional medical services (medical and prosthetic service). It should be noted that in the discussed example, the dentist is the main decision-maker in relation to the provision of the service. The dentist makes decisions both about the type of prosthetic treatment, as well as the materials and technologies used. However, with regard to the material aspect of the implementation of the dentistry is the middleman between the demands of the customer (patient) and the contractor of the prosthesis (dental technician).

The quality assessment of the relationships created in the business-to-customer and businessto-business should be conducted in terms of a particles set. This paper presents a proposal to evaluate the quality of the relationship between the patient and the dentist as well as the dentist and dental technician based on (appropriate) principle of quality management: customer orientation, leadership, commitment of people, process approach, continuous improvement, evidence-based decision making, and mutual 
benefits in relations with stakeholders. It has been presented how divergent perceptions of process participants are. It can be noticed that in the patient-dentist relation, dentists assess the quality management method in the $\mathrm{B} 2 \mathrm{C}$ relation much better. The evaluations indicate that according to dentists, the selected principles are fully met, while patients have considerable doubts about the quality of management in these areas. The results confirm the quite idealistic approach of dentists to the method of managing the quality of the service delivery process. It can be seen that dentists did not allocate such optimistic assessments when assessing the quality of relationships with dental techniques (B2B). A greater criticism to the fulfillment of quality management principles results from the fact that in this relationship they are a customer. Such a large discrepancy indicates the need to introduce appropriate standardization for the execution of orders both in the B2C and B2B systems.

Additionally, on the basis of the results obtained, areas that are analyzed in a separate manner and areas that are certainly weak points in the quality management of the discussed relations are indicated. The biggest differences between the perception of service quality in B2C system have been noted for principles 2 leadership and 7 - mutual benefits in relations with stakeholders. Whereas, the biggest differences between the perceptions of service quality in B2C system have been noted for principles 1 - customer orientation and 6 - evidence-based decision making.

\section{References}

Ashley, C., Noble, S. M., Donthu, N., \& Lemon, K. N. (2011). Why customers won't relate: obstacles to relationship marketing engagement. Journal of Business Research, 64(7), 749-756.

https://doi.org/10.1016/j.jbusres.2010.07.006

Brink, T. (2017). B2B SME management of antecedents to the application of social media. Industrial Marketing Management, 64(2017, July), 57-65. https://doi.org/10.1016/j.indmarman.2017.02.007

Cheng, L. M., Choi, W. P. C., \& Wong, A. Y. M. (2016). A novel client service quality measuring model and an eHealthcare mitigating approach. International Journal of Medical Informatics, 91(2016, July), e16-e31. https://doi.org/10.1016/j.ijmedinf.2016.03.003

Chu, B., \& Hsu, Y. (2017). Non-audit services and audit quality - the effect of Sarbanes-Oxley Act. Asia Pacific Management Review, 23(3), 201-208. https://doi.org/10.1016/j.apmrv.2017.07.004

Çifci, S., Ekinci, Y., Whyatt, G., Japutra, A., Molinillo, S., \& Siala, H. (2016). A cross validation of ConsumerBased Brand Equity models: Driving customer equity in retail brands. Journal of Business Research, 69(9), 3740-3747.

https://doi.org/10.1016/j.jbusres.2015.12.066

Dant, R., \& Brown, J. (2008). Bridging the B2C and B2B Research Divide: The domain of retailing literature. Journal of Retailing, 84(4), 371-397. https://doi.org/10.1016/j.jretai.2008.09.005

Fatima, J. K., \& Di Mascio, R. (2018). Reversing the dependency-trust relationship in B2C services. Journal of Retailing and Consumer Services, 41(2018, March), 1-10.

https://doi.org/10.1016/j.jretconser.2017.11.005

Gao, T., Sirgy, M. J., \& Bird, M. M. (2005). Reducing buyer decision-making uncertainty in organizational purchasing: can supplier trust commitment, and dependence help? Journal of Business Research, 58(4), 397405. https://doi.org/10.1016/S0148-2963(03)00137-1

Gharib, R. K., Philpott, E., \& Duan, Y. (2017). Factors affecting active participation in B2B online communities: An empirical investigation. Information \& Management, 54(4), 516-530.

https://doi.org/10.1016/j.im.2016.11.004

Gulc, A. (2017). Models and methods of measuring the quality of logistic service. Procedia Engineering, 182, 255-264. https://doi.org/10.1016/j.proeng.2017.03.187

Gutacker, N., Harris, A., Brennan, D., \& Hollingsworth, B. (2015). The determinants of dentists' productivity and the measurement of output. Social Science \& Medicine, 124(2015, January), 76-84.

https://doi.org/10.1016/j.socscimed.2014.11.020

Iankova, S., Davies, I., Archer-Brown, C., Marder, B., \& Yau, A. (2018). A comparison of social media marketing between B2B, B2C and mixed business models. Industrial Marketing Management, (2018, January).

https://doi.org/10.1016/j.indmarman.2018.01.001

Ingaldi, M. (2016). Use of the servperf method to evaluate service quality in the transport company. Independent Journal of Management \& Production, 7(1), 168-177. https://doi.org/10.14807/ijmp.v7i1.396

Kasiri, L. A., Guan Cheng, K. T., Sambasivan, M., \& Sidin, S. M. (2017). Integration of standardization and customization: Impact on service quality, customer satisfaction, and loyalty. Journal of Retailing and Consumer Services, 35(2017, March), 91-97. https://doi.org/10.1016/j.jretconser.2016.11.007

Klimecka-Tatar, D. (2017). Value stream mapping as Lean production tool to improve the production process organization - case study in packaging manufacturing. Production Engineering Archives, 17, 40-44. https://doi.org/10.30657/pea.2017.17.09

Kowalik, K., \& Klimecka-Tatar, D. (2017). TQM i Lean Management jako koncepcje zarzadzania rozwojem przedsiębiorstwa nastawionego na doskonalenie jakości. Wybrane problemy zarządzania nowoczesną organizacją we współczesnej gospodarce. D. Wielgórka (red.). Wydawnictwo Wydziału Zarządzania Politechniki Częstochowskiej, Częstochowa, 48-57.

Lee, W.-H., \& Cheng, C.-C. (2018). Less is more: A new insight for measuring service quality of green hotels. International Journal of Hospitality Management, 68(2018, January), 32-40. https://doi.org/10.1016/j.ijhm.2017.09.005

Lilien, G. L. (2016). The B2B knowledge gap. International Journal of Research in Marketing, 33(3), 543-556. https://doi.org/10.1016/j.ijresmar.2016.01.003 
Liu, Y., Foscht, T., Eisingerich, A. B., \& Tsai, H.-T. (2017). Strategic management of product and brand extensions: Extending corporate brands in B2B vs. B2C markets. Industrial Marketing Management. 71(2018, May), 147-159.

https://doi.org/10.1016/j.indmarman.2017.12.016

Lussier, B., \& Hall, Z. R. (2017). Cooperation in B2B relationships: Factors that influence customers' perceptions of salesperson cooperation. Industrial Marketing Management. 69(2018, February), 209-220. https://doi.org/10.1016/j.indmarman.2017.09.019

Madhavaram, S., \& Hunt, S. D. (2017). Customizing business-to-business (B2B) professional services: The role of intellectual capital and internal social capital. Journal of Business Research, 74(2017, May), 38-46. https://doi.org/10.1016/j.jbusres.2017.01.007

Meidutè-Kavaliauskienè, I., Aranskis, A., \& Litvinenko, M. (2014). Consumer satisfaction with the quality of logistics services. Procedia - Social and Behavioral Sciences, 110(2014, January), 330-340. https://doi.org/10.1016/j.sbspro.2013.12.877

Murphy, M., \& Sashi, C. M. (2018). Communication, interactivity, and satisfaction in B2B relationships. Industrial Marketing Management, 68(2018, January), $1-12$. https://doi.org/10.1016/j.indmarman.2017.08.020

Nowacki, R., Szopiński, T. S., \& Bachnik, K. (2017). Determinants of assessing the quality of advertising services - The perspective of enterprises active and inactive in advertising. Journal of Business Research. 88(2018, July), 474-480.

https://doi.org/10.1016/j.jbusres.2017.12.017

Pansari, A., \& Kumar, V. (2017). Customer engagement: The construct, antecedents, and consequences. Journal of the Academy of Marketing Science, 45(3), 294-311. https://doi.org/10.1007/s11747-016-0485-6

Ulewicz, R., \& Kucęba, R. (2016). Identification of problems of implementation of Lean concept in the SME sector. Economics and Management, 8(1), 19-25. https://doi.org/10.1515/emj-2016-0002

Vrontis, D., Thrassou, A., \& Amirkhanpour, M. (2017). B2C smart retailing: A consumer-focused value-based analysis of interactions and synergies. Technological Forecasting and Social Change, 124(2017, November), 271-282.

https://doi.org/10.1016/j.techfore.2016.10.064

White, G., Nallur, V., \& Clarke, S. (2017). Quality of service approaches in IoT: A systematic mapping. Journal of Systems and Software, 132(2017, October), 186-203. https://doi.org/10.1016/j.jss.2017.05.125

Zolkiewski, J., Story, V., Burton, J., Chan, P., Gomes, A., Hunter-Jones, P., O’Malley, L., Peters, L. D., Raddats, C., \& Robinson, W. (2017). Strategic B2B customer experience management: The importance of outcomes-based measures. Journal of Services Marketing, 31(2), 172-184.

https://doi.org/10.1108/JSM-10-2016-0350 